\title{
AUTO EVALUATIONS OF DISTANCE MANAGEMENT TRAINING IN A FEDERAL AUTARCHY
}

\author{
LEOVANIR D. D. RICHTER \\ Ministério da Transparência e Controladoria Geral da União (CGU), Brasília, DF, Brazil
}

To cite this paper: Richter, L. D. D. (2018). Auto evaluations of distance management training in a federal autarchy. Revista de Administração Mackenzie, 19(2). doi:10.1590/1678-6971/eRAMG180100

Submission: Sep. 26, 2017. Acceptance: Dec. 19, 2017.

\section{(cc) $\mathbf{B Y}$} This is an open-access article distributed under the terms of the Creative Commons Attribution License.

\footnotetext{
This paper may be copied, distributed, displayed, transmitted or adapted if provided, in a clear and explicit way, the name of the journal, the edition, the year and the pages on which the paper was originally published, but not suggesting that RAM endorses paper reuse. This licensing term should be made explicit in cases of reuse or distribution to third parties. It is not allowed the use for commercial purposes.

Este artigo pode ser copiado, distribuído, exibido, transmitido ou adaptado desde que citados, de forma clara e explícita, o nome da revista, a edição, o ano e as páginas nas quais o artigo foi publicado originalmente, mas sem sugerir que a RAM endosse a reutilização do artigo. Esse termo de licenciamento deve ser explicitado para os casos de reutilização ou distribuição para terceiros. Não é permitido o uso para fins comerciais.
} 


\section{ABSTRACT}

Purpose: The self-evaluation of management training had the objective of verifying the influence of the learning support and of the management training offered to managers of a Brazilian federal autarchy on the expression of competences required for the performance of their duties. Originality/value: To reach this objective, the hypothesized theoretical model of research was elaborated having as variables the criteria of training impacts in the labor, measured both in depth and in amplitude, measured on what was the importance and contribution of two evaluated courses for the acquisition and expression of management-labor skills. Design/methodology/approach: Regarding the methodology, two courses were offered in the distance modality, in this autarchy, which dealt with strategic management and teams. Data collection was performed at a distance. The final sample $(\mathrm{N}=291)$ was predominantly male, between 31 and 50 years old, and with complete graduate education.

Findings: The results showed a valid and construct evidence for the used measures, as well as pointed out that learning support was an important predictor in the final empirical models. Having a constant investment in actions to improve learning support in the organizational environment, such managers can apply in their routines the skills acquired in a training situation, in a more persistent, impactful and aligned with the strategic objectives of the autarchy.

\section{KEYWORDS}

Impact of training at work. Support to learning. Organizational competences. Training results. People management. 


\section{INTRODUCTION}

The changing nature of leadership in public organizations has been particularly important in the development of the new public service, according to Denhardt (2012, p. 262). Practical public managers, who seek greater commitment to values, focus on public service, empowerment, shared leadership, pragmatic increments and dedication to the public service, consequently reflecting a business model that makes the public service different through the promotion of dignity and value of the new public service.

With the initial awakening of the characteristics of the practical public manager, this research was developed in a federal autarchy, to the occupants of a commissioned function of executive manager and customer service manager. This public was selected because it performs management activities in the various administrative and service areas that exist in the Brazilian territory, with needs and characteristics that need to be considered in training carried out by this autarchy and that was shown in this research.

The problem identified by this research was what the contributions of distance management training are expressed by the managers of the autarchy around their competences required for the performance of their duties. The importance attributed to each of the two distance courses analyzed on the development of management competencies within the researched individuals was investigated. Furthermore, it was intended to measure how far each distance course in specific contributed, effectively, to the development of these management competencies. It was concluded that the impact of the two distance courses would be measured on the importance of these courses to the development of management competencies and how, in fact, under the perception of the respondents, these courses contributed to the development of these competencies. This perspective (considering the effects of the impact of training on the development of professional competencies) can be considered relatively innovative since little instructional technology refers to the later development and expression of the competences, especially those of management level. The theoretical perspective assumed in this research is based on Elnaga and Imran (2013) and Alfandi (2016).

This problem guided the general objective of evaluating the effectiveness of distance management training in light of the skills required from autarchy managers through self-evaluation measures and variables that predict training results.

The social relevance of the proposed study is to evaluate the educational actions aimed at the training of managers, which may favor the evolution of 
distance courses, allowing the increase of the quality of the services provided by the autarchy. Regarding the organizational relevance, the research can contribute to improving the TD\&E (training, development and performance improvement) actions of this autarchy, making it possible the rationalization of public resources and the improvement of services provided to the Brazilian population, as well as encouraging the increase of the evaluation culture of the courses to distance promoted by it.

\section{THEORETICAL SUBSTANTIATION}

The authors Aguinis and Kraiger (2009) present a literature review on the benefits of training and development of people and teams, organizations and society. They bring a review of assessment needs and training projects. They point out that there is documentary evidence that training activities have a positive impact on the performance of individuals and teams.

In Brazil, the review of human resource management by Meneses, Coelho Junior, Ferreira, Paschoal, and Silva Filho (2014, p. 129) is marked by theoretical-empirical studies aimed at describing certain facets - the management of human resources functions, such as training, development and education, from the perception of diverse audiences sampled in a nonprobabilistic way in one organization at a time.

Considering such revisionary researches, it is perceived that human learning at work has a plurality of concepts and definitions, in which the concept of Abbad and Borges-Andrade (2014, p. 244) was adopted in this study, which maintains that learning "is a psychological process understood as the changes that occur in the behavior of the individual as a function of the relationship of the individual with the environment and not only changes resulting solely from maturation."

By observing the importance of the transfer of learning at work with the use of knowledge, skills and attitudes (KSAs), in terms of effectiveness in the performance of the trained competence, there are factors to be explained, according to Noe, Clarke, and Klein (2014), to know: 1. whether the evaluation of the transfer takes place sometime after the training or if it is soon after the training, 2. if the evaluation of the transfer is a result of the perception of the trainees themselves or of their peers; 3 . if the concept of transference is operationalized as an application in the work of what was learned by the individual or in terms of performance effectiveness of the trained competence. 
According to Kraiger and Cavanagh (2015), this is a systematic process managed by organizations, with constant changes in the knowledge, skills, and attitudes of their occupants. This process occurs through 1. management of the education system (as a process), 2. conducting a needs assessment training to define the content of the training, 3. training project, 4. provision of training, 5. management of the transfer of the training back to work, and 6. assessment of the impact of the training and review of the education system based on these data.

Training is considered an activity materialized by different rhythms, with different visions, implemented according to various ends and regulated by the dynamics of economic competition, according to Alfandi (2016). As an institutionalized service, training is structured on labor activity, being a transcendent object that has covered the societies, contingencies, political systems, and economic conditions.

Training has always been a mandatory means to promote the qualification of the workers needed for each management logic. Malvezzi (2015) emphasizes that throughout its historical trajectory, training has faced several types of challenges that only served to enrich it and allowed it to evolve, integrated around work performance and the emancipation of the individual as a human being and not a mere human resource in organizations.

When observing the e-learning (electronic learning), object of this research, it is perceived that it is a modality usually turned to the learning of adults. In Brazil, e-learning is being adopted in education, in qualification and professional training programs, and incorporate education (Abbad, 2007).

When considering the necessary e-learning and viable its use for the management capacities in the structure of the selected autarchy, the assessment of the teaching-learning process also needs to be weighed.

According to the studies of Bloom, Hastings, and Madaus (1983), the evaluation of the teaching-learning process presents three types of functions: diagnostic (analytical), formative (controlling) and summative (classificatory). The summative evaluation that is the object of this research, according to Borges-Andrade (2006, p. 344), "is the process of planning, obtaining and analyzing information in order to provide useful inputs to decide on the adoption or rejection of a program or event isolated from TD\&E, thought as an instructional system."

In the scientific literature, two models of training evaluation are pointed out. Kirkpatrick (1976) suggests four levels of evaluation: 1. reactions; 2. learning; 3. performance in the position; 4. results. The Hamblin model 
(1978) subdivides the results item, with the following presentation: 1. reactions; 2 . learning; 3 . performance in the position; 4 . organizational change; and 5 . final value.

The more contemporary models mix training results with environment variables. In this line, CIRO (Warr, Bird, \& Rackham, 1970), CIPP 48 (Stufflebeam, 1978), MAIS (Borges-Andrade, 1982) and IMPACT (Abbad, 1999; Abbad, 2014) can be cited.

The Integrated Impact Assessment of Training (IMPACT), elaborated by Abbad (1999) and revised in 2014, based on the MAIS of Borges-Andrade (1982), was the model chosen in this study as a variable training impact criterion (in amplitude), also encompassing context variables of learning support. The IMPACT Model consists of ten components: 1. external environment; 2 . support; 3 . needs; 4 . customer characteristics; 5 . training characteristics; 6 . reactions; 7 . learning; 8 . impact of training on the job; 9. change in the organization; and 10. final value. The first seven components are predictive variables of the impact of training at work.

The amplitude impact assessment contains items related to the frequency of use of learning, improvement of the quality of task performance, reduction of errors in the execution of the task and items that evaluate the impact of training on the motivation and self-efficacy of the trained professional. The in-depth impact assessment has items drawn from the instructional objectives (transformed into expected performance objectives) specific to each training.

In addition to the training impact assessment, it is necessary to conceptualize the learning support variable, which is one of the critical factors for the effective use of training in the work environment.

According to Coelho Jr. (2004, p. 56), support for learning is an evaluation of psychosocial support (peers, peers and bosses) for learning and applying new skills in the work environment, acquired not only through previously planned training (induced learning), but also by learning in unstructured or unintentional organizational situations (natural learning).

For Abbad et al. (2012, p. 247), learning support is "evaluated in terms of stimulating the organizational environment to new spontaneous learning at work through contact with more experienced people, self-learning or imitation behavior" and deals with dimensions of support as creating positive expectations about the benefits of learning and its application, providing feedback, and disseminating information about competent performance.

When dealing with competences, it is opportune to start the theoretical basis from the contributions of McClelland (1973) and Boyatzis (1982), 
since they are considered the forerunners in this theme. They depart from the American school and propose competences as inputs, that is, the qualities required for the exercise of a position, related only to the set of KSAs.

Sandberg (1996) criticizes the traditional concept of competences, where it understands that the development of competences must be understood based on organizational practices, focusing its analysis on the enrichment of experiences and experiences (interpretative approach).

Due to the importance of such concept of competences, it is observed that in the literature there are many definitions of respect. To identify differences and convergences in the technical use of such concept, Campos (2015) carried out a systematic analysis in the specialized scientific literature.

In this analysis, Campos (2015) identified three dimensions along the concept of competences around attributes underlying the dimension of knowledge, skills, and attitudes. This concept of competences is an observable performance in the dimension of behaviors and results; performance in the dimension of excellence and recognition.

Campos (2015, p. 34) points out that:

The concept of competence expresses individual attributes depending on the context, which vary according to the situation (unforeseen, changes) and with the work to be performed. For this reason, evaluating only facts or isolated occurrences of human work performance and results are inadequate and inadequate methodological strategies for the measurement of human competences. Also, the concept of competence includes standards and reference values adopted by a particular social unit (organization, team, other people) to judge whether a given performance is competent and whether or not the result of that performance is an indicator of success.

In this research, competence, as conceptualized by Carbone (2009), is considered a set of synergetic combinations of knowledge, skills, and attitudes expressed by professional performance within an organizational context, which adds value to people and organizations.

For Brandão, Borges-Andrade, Freitas, and Vieira (2010) management skills are a category that has attracted growing interest from theorists, organizations, and researchers, perhaps because of the supposition that they exert considerable influence on the performance of work teams, and therefore on organizational outcomes. Despite the efforts that have been made, mainly in the theoretical field, to explain the nature of management competence, 
many questions remain unanswered, lacking research to investigate antecedents and consequent of the expression of competences at work, wherein this research variable is contemplated.

In light of the brief theoretical background presented, it is intended to fix the work on the impact of training, support to learning and skills, wherein the next section, the methodological procedures of this research are presented.

\section{METHODOLOGY}

The proposed theoretical research model had as variables the criteria of training impacts in work both in depth and breadth, including verifying their effects on competences required from the managers of a certain Brazilian federal autarchy. It is expected that the greater the perceived influence (training impact in depth and breadth) there will be greater importance and contribution of the two courses evaluated against the competences required from such managers.

With the favorable perception of the influences of training in the work environment, more skills can be aggregated and related to the training and the professional day to day. It is already emphasized here that the measure of the breadth of competencies was built based on the competences established for the occupants of the executive manager and service manager of the selected autarchy, based on the management skills scale proposed by Brandão, Borges-Andrade, Freitas, and Vieira (2010). In this research, unlike Brandão et al. (2010), only self-evaluation measures were used.

The empirical model developed here (which has as variables the criterion of depth and amplitude of training impacts on the acquisition and expression of management competences in work) was conceived from variables contained in the IMPACT model (Abbad, 1999).

The following predictors were tested: 1 . clientele profile, which contains the biographical and functional information regarding the participants of the two training sessions under analysis; 2. learning support (psychosocial support of colleagues and leadership to the application of new learning in work performance).

According to Abbad et al. (2012), learning support has been considered as the main predictor of the impact of training, since it assumes that the existence of an organizational context favorable to the use of new skills learned in training generates conditions for impact. 
The impact was not measured only in the way traditional TD\&E literature does, but also considered the outcome of each of the impacts reported on the development of management competences. It was considered the importance attributed to each training to the improvement of postqualification work performance as well as how effectively, from the perspective of individuals, each of the two courses evaluated contributed to the improvement of this professional performance.

Therefore, it was verified, in this model, the relationship of personal, professional and learning support predictor variables along with the variables of the impact criterion of training in depth and amplitude on acquisition and expression of management competences with executive managers and managers of this autarchy.

To operationalize the empirical investigation of such theoretical variables, a single questionnaire was designed for such managers, considering all the items of each of the measures under study, duly grouped. This questionnaire also included demographic and functional information.

The theoretical hypothesized model was conceived based on the analysis of the literature described in the theoretical foundation. He considered that in a management and peer support environment, with the deep impact and breadth of management skills, there would be acquisition and expression (stages conceived here as equivalents of competency domain) of skills and knowledge acquired from these training in the work routine.

For a better visualization of the proposed research, the hypothesized theoretical model is presented in Figure 3.1.

\section{(Figure 3.1)}

\section{HYPOTHESIZED THEORETICAL MODEL OF TRAINING IMPACT, LEARNING SUPPORT AND PERSONAL AND PROFESSIONAL CHARACTERISTICS}

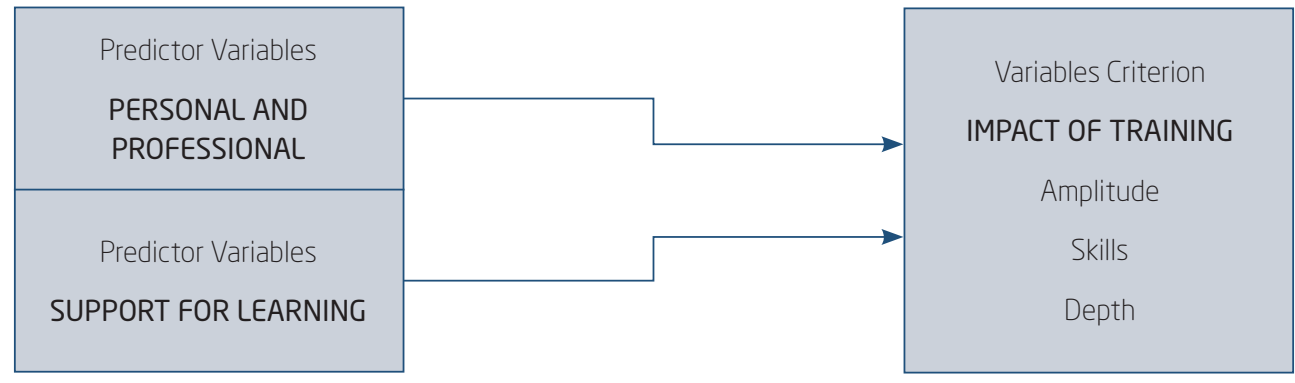

Source: Elaborated by the author. 
The typification of this research had an applied, theoretical/empirical nature and a descriptive research delineation from a correlational perspective, analyzing the self - perceptions of the training impact, the learning support and the skills required from certain managers of a Brazilian federal autarchy. Being correlational this research, statistical indices were used to verify the possible influence among the identified variables with analysis of the questionnaire responses sent to the 104 executive managers and 1,506 service managers.

The scope was of the case, through the evaluation of two management capacities at a distance in the autarchy regarding the impact and the learning support, verifying if they promote the established management competencies.

The approach is classified as quantitative, since the data were obtained through indirect contact between the researcher and the situation of the study, with a cross-sectional data collection, cross-sectional (cross-sectional), since the data were collected at a given time, from July 2016 to August 2016, with no intention of tracing evolution or identifying changes over time (Churchill Junior, 1999, p. 66). It was done through the use of an electronic questionnaire - survey type in a field environment, applied to the executive managers and managers of distributed service of the autarchy in the Brazilian territory.

In this research, the primary data collected by the researcher were used, considering that descriptive research was carried out on the distance training required for the 104 executive managers and 1,506 service managers to generate hypotheses regarding the efficiency, effectiveness and effectiveness of these distance training models front the skills required to perform these functions in the autarchy, resulting in an intentional non-probabilistic sample, according to Creswell (2010), with managers participating in distance training from January/2013 to March/2016.

\subsection{Collection of primary data}

The research questionnaire, covering all variables that were searched in this study, contained a total of 111 items. The items concerning the learning support scale have already been previously tested and validated empirically (Coelho Junior, 2004), and it is still necessary to adopt procedures for semantic validation and adequacy of these items to the language and culture of the Organization under study.

The in-depth impact items were elaborated according to the instructional objectives of each selected course, having five questions that assessed both 
the importance and the contribution of the course to the professional performance. These instructional objectives were elaborated by the autarchy itself in 2010 and transformed in this research into performance objectives. It should be noted that for data analysis, all the items contained in the measure made available by the Organization were not used because they are not of interest to this research at the moment.

The amplitude impact questionnaire items were structured on Abbad's (1999) Integrated Impact Assessment (Impact) model and recently revised by Abbad (2014). In this dimension of the questionnaire, in addition to the 13 questions of the Impact model, four additional questions were added to the reality of the autarchy searched.

In Table 3.1.1, below, is a summary of the theoretical dimensions of all the items that composed the research instrument made available electronically to the graduates of the two distance courses selected.

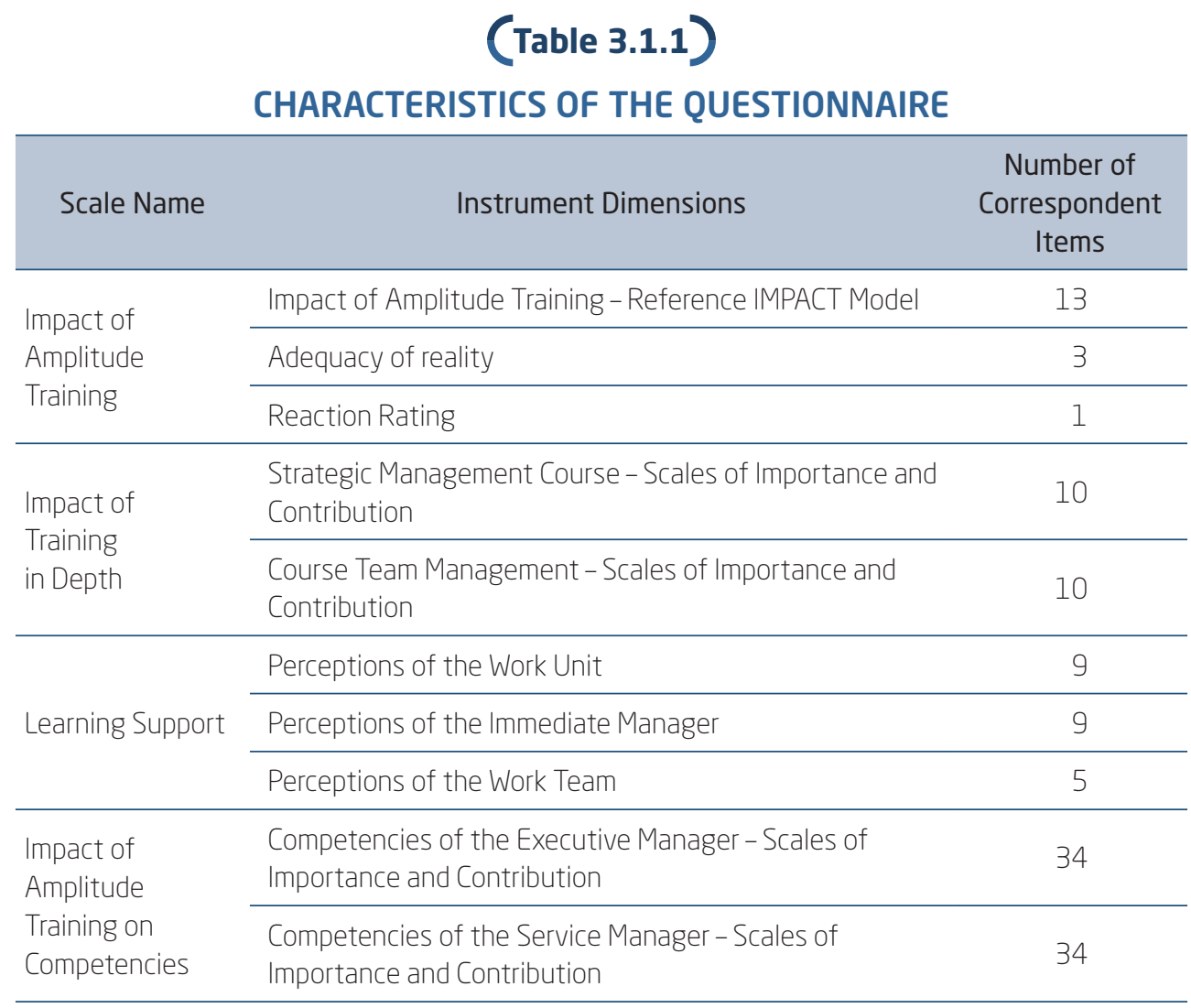




\section{(Table 3.1 .1 (conclusion))}

CHARACTERISTICS OF THE QUESTIONNAIRE

\begin{tabular}{llc}
\multirow{2}{*}{ Scale Name } & \multicolumn{1}{c}{$\begin{array}{c}\text { Number of } \\
\text { Instrument Dimensions }\end{array}$} & $\begin{array}{c}\text { Correspondent } \\
\text { Items }\end{array}$ \\
\hline \multirow{2}{*}{$\begin{array}{l}\text { Training } \\
\text { Requests }\end{array}$} & Self-Training & 1 \\
\cline { 2 - 3 } & Work Team & 1 \\
\cline { 2 - 3 } Functional & Substitute Manager & 1 \\
\cline { 2 - 3 } Manager & Profile & 11 \\
\hline
\end{tabular}

Source: Elaborated by the author.

The application of the electronic questionnaire was done through the electronic mail of the autarchy and occurred in July and August 2016, inviting the 104 executive managers and 1,506 service managers to participate in the survey, with a population and total target audience of 1,610 managers, through the provision of a link in the free software LimeSurvey. Instructions for completing the instrument were self-explanatory since the collection was performed at a distance.

Considering 1,610 managers linked to this research, a return of 291 respondents ( $18 \%$ return rate) was obtained, where the questionnaires were sent to the population. The return was spontaneous, generating a non-random sample of respondents. Of the 291 participants, 30 identified themselves as executive managers and 261 as service managers, representing $29 \%$ and $17 \%$, respectively, compared to the population of 104 executive managers and 1,506 service managers.

Of these 291 participants, 114 were females and 177 males, with schooling distributed in high school with 15 participants, incomplete superior with 36 , complete superior with 161, specialization with 74 and masters with 5 participants. The public service time of the 291 participants was more representative with $30 \%$ in the period superior to 15 years and in the management function with the greater representativeness of $35 \%$ in the period of 1 to 3 years.

Geographic participation was representative and balanced throughout the country, with $28 \%$ in the North and Midwest, $34 \%$ in the Southeast, $15 \%$ in the South and $22 \%$ in the Northeast. The state with the largest participation was Minas Gerais with 14\%. 


\section{ANALYSIS OF RESULTS}

First, evidence of the internal validity of the questionnaire used focuses on the specific analysis of its underlying theoretical dimensions (learning support and training impact on breadth and depth). Subsequently, the final empirical models obtained were presented. Procedures involving the tabulation of data and calculations were performed using the SPSS program (Statistical Package for the Social Sciences).

\subsection{Factorial analyzes of the questionnaire}

The factorability was tested by the Kaiser-Meyer-Olkin index, known as the suitability index of the sample, and by Bartlett's sphericity test, as recommended by Tabachnick and Fidell (2007). After that, the data were submitted to principal component analysis (PCA), main axis factoring (MAF) and factors reliability were estimated by Cronbach's alphas, via SPSS.

According to Hair Junior, Black, Babin, Anderson, \& Tatham (2006), it is important to point out that the criterion used for eigenvalues must have at least one associated eigenvalue equal to 1 . The tested rotation between the factors for each dimension (learning support and impacts) was Varimax. Table 4.1.1. shows the psychometric indicators of each block.

(Table 4.1.1)

SYNTHESIS OF FACTORIAL ANALYZES

\begin{tabular}{|c|c|c|c|c|c|}
\hline Block & Items & KMO & $\begin{array}{l}\text { Factorial } \\
\text { Charges }\end{array}$ & $\begin{array}{c}\text { Cronbach's } \\
\text { Alpha }\end{array}$ & $\begin{array}{l}\text { Variance } \\
\text { Explained }\end{array}$ \\
\hline \multirow{4}{*}{ Learning Support } & Unit of work- 8 & \multirow{4}{*}{0,85} & \multirow{4}{*}{0,41 to 0,81} & 0,82 & \multirow{4}{*}{$54 \%$} \\
\hline & Immediate Manager - 5 & & & 0,85 & \\
\hline & Work Team - 5 & & & 0,79 & \\
\hline & Inadequate Support - 5 & & & 0,65 & \\
\hline Impact amplitude & Impact-16 & 0,96 & 0,75 to 0,90 & 0,95 & $66 \%$ \\
\hline \multirow{2}{*}{$\begin{array}{l}\text { Impact in depth - } \\
\text { Strategic } \\
\text { Management }\end{array}$} & Importance- 5 & 0,89 & 0,85 to 0,92 & 0,93 & $78 \%$ \\
\hline & Contribuiton- 5 & 0,87 & 0,80 to 0,91 & 0,92 & $76 \%$ \\
\hline
\end{tabular}


(Table 4.1.1 (conclusion))

SYNTHESIS OF FACTORIAL ANALYZES

\begin{tabular}{|c|c|c|c|c|c|}
\hline Block & Items & KMO & $\begin{array}{l}\text { Factorial } \\
\text { Charges }\end{array}$ & $\begin{array}{c}\text { Cronbach's } \\
\text { Alpha }\end{array}$ & $\begin{array}{l}\text { Variance } \\
\text { Explained }\end{array}$ \\
\hline \multirow{2}{*}{$\begin{array}{l}\text { Impact in depth - } \\
\text { Team } \\
\text { Management }\end{array}$} & Importance - 5 & 0,87 & 0,82 to 0,90 & 0,92 & $76 \%$ \\
\hline & Contribuiton- 5 & 0,89 & 0,87 to 0,92 & 0,94 & $80 \%$ \\
\hline \multirow{2}{*}{$\begin{array}{l}\text { Impact on breadth } \\
\text { of responsibilities } \\
\text { of the service } \\
\text { manager }\end{array}$} & Importance-17 & 0,87 & 0,30 to 0,73 & 0,87 & $32 \%$ \\
\hline & Contribuiton-17 & 0,87 & 0,43 to 0,73 & 0,88 & $34 \%$ \\
\hline
\end{tabular}

In Appendix I, we present parts of the factorial loads of each research block, describing the items of learning support, impact on breadth, depth of impact, and breadth of impact on the competencies of the service manager.

For a better understanding of the factorial analyzes carried out in this research, it is shown that the learning support block presents values not so close to 0 and not as close to 1 in the analysis of the commonality matrix, characterizing a satisfactory factorial solution. The component matrix identified in the learning support block is formed by the four factors: 1 . Work Unit, 2. Immediate Manager, 3. Work Team, and 4. Inadequate Support; that explain $54 \%$ of the variance already mentioned, generating factorial loads between 0.13 and 0.81 ; the partial results of which are given in Table 1 of Appendix I.

It should be noted that it was not possible to perform the factorial analysis of the executive managers, considering the answers given by the 30 executive managers in relation to the importance perceived by the course to the development of competences and how much the courses allowed the domain of professional competences be related to the work. This is because sufficient variability (small sample) was not found.

\subsection{Empirical models}

We present here the empirical results obtained with the statistical regression models, which are separated by the variable training impact criterion and the predictive variable of learning support with their respective 
factors of the work unit, immediate manager, work team and support. In Tables 3 to 6 , the final and significant results of such models generated in the SPSS are synthesized, using as a criterion of permanence in the model the probability values of $F<0.05$, starting with the Impact in Amplitude criterion.

\section{(Table 4.2.1)}

SYNTHESIS OF THE EMPIRICAL MODEL - VARIABLE IMPACT CRITERION IN AMPLITUDE AND PREDICTIVE VARIABLE OF LEARNING SUPPORT

\begin{tabular}{|c|c|c|c|c|c|c|}
\hline \multirow{2}{*}{ 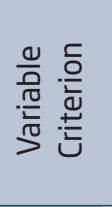 } & & \multirow{2}{*}{ Model } & \multicolumn{2}{|c|}{$\begin{array}{l}\text { Non-standardized } \\
\text { coefficients }\end{array}$} & \multirow{2}{*}{$\begin{array}{c}\text { Standardized } \\
\text { Coefficient }\end{array}$} & \multirow{2}{*}{$R$ squared } \\
\hline & & & B & $\begin{array}{l}\text { Standard } \\
\text { Template }\end{array}$ & & \\
\hline \multirow{5}{*}{ 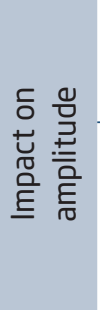 } & & Constant & 2,59 & 0,43 & & \\
\hline & & Factor: Unit of work & 0,61 & 0,06 & 0,50 & 0,25 \\
\hline & & Constant & 2,12 & 0,46 & & \\
\hline & 2 & Factor: Unit of work & 0,51 & 0,07 & 0,41 & 0,27 \\
\hline & & Factor: Immediate Manager & 0,17 & 0,06 & 0,17 & \\
\hline
\end{tabular}

Regarding the variable criterion impact of training in amplitude the final empirical model indicated that only Workplace Learning Support $(\beta=0.41)$ and the Boss $(\beta=0.17)$ predicted significantly Impact measured in Amplitude. This finding is in line with what Coelho Junior, Abbad, \& Todeschini (2005) point out, where the support variable is, in fact, the one that most explains the impact of the training.

In-depth training impact was analyzed considering the two courses currently investigated (strategic management and team management). This impact was analyzed here in terms of the importance and contribution of each of the two courses for the development of competences and later performance of the manager.

The final model indicated that only the learning support of the immediate manager was able to significantly predict the impact in depth in the distance course of strategic management in terms of its importance for the development of professional skills oriented to the manager's job performance. 
It also indicated that the support to the immediate manager's learning and the lack of support significantly predicted the impact in depth in the strategic management course, in terms of their perceived contribution to the acquisition and mastery of professional skills oriented to the manager's job performance.

\section{(Table 4.2.2)}

SYNTHESIS OF THE EMPIRICAL MODEL - VARIABLE IMPACT CRITERION IN DEPTH AND VARIABLE PREDICTOR OF LEARNING SUPPORT DISTANCE COURSE OF STRATEGIC MANAGEMENT

\begin{tabular}{|c|c|c|c|c|c|c|c|}
\hline \multirow{2}{*}{ 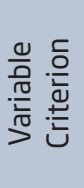 } & & & \multirow{2}{*}{ Model } & \multicolumn{2}{|c|}{$\begin{array}{l}\text { Non-standardized } \\
\text { coefficients }\end{array}$} & \multirow{2}{*}{$\begin{array}{c}\text { Standardized } \\
\text { Coefficient }\end{array}$} & \multirow{2}{*}{$R$ squared } \\
\hline & & & & B & $\begin{array}{l}\text { Standard } \\
\text { Template }\end{array}$ & & \\
\hline \multirow{7}{*}{ 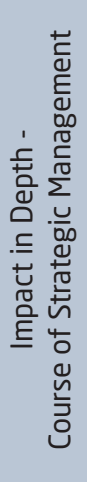 } & \multirow{2}{*}{ 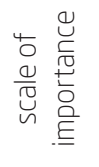 } & \multirow{2}{*}{1} & Constant & 2,20 & 0,15 & & \\
\hline & & & Factor: Immediate Manager & 0,13 & 0,02 & 0,36 & 0,13 \\
\hline & \multirow{5}{*}{ 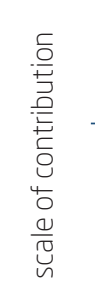 } & \multirow{2}{*}{1} & Constant & 2,06 & 0,15 & & \\
\hline & & & Factor: Immediate Manager & 0,14 & 0,02 & 0,37 & 0,14 \\
\hline & & \multirow{3}{*}{2} & Constant & 1,75 & 0,17 & & \\
\hline & & & Factor: Immediate Manager & 0,15 & 0,02 & 0,39 & 0,17 \\
\hline & & & Factor: Lack of Support & 0,08 & 0,02 & 0,18 & \\
\hline
\end{tabular}

Source: Elaborated by the author.

In the distance course of team management, it was verified that the only predictor identified for the variable criterion was the support to the perceived learning in the work unit, in the importance and contribution scales, as shown in Table 4.2.3.

With respect to the variable of the impact of training in amplitude on competences of the manager of care, the only predictor was a support to the perceived learning in the unit of work, both in the scale of importance and in the scale of contribution, according to Table 4.2.4. 


\section{(Table 4.2.3)}

SYNTHESIS OF THE EMPIRICAL MODEL - VARIABLE IMPACT CRITERION IN DEPTH AND VARIABLE PREDICTIVE OF LEARNING SUPPORT DISTANCE COURSE OF TEAM MANAGEMENT

\begin{tabular}{|c|c|c|c|c|c|c|c|}
\hline \multirow{2}{*}{ 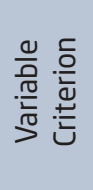 } & & & \multirow{2}{*}{ Model } & \multicolumn{2}{|c|}{$\begin{array}{l}\text { Non-standardized } \\
\text { coefficients }\end{array}$} & \multirow{2}{*}{$\begin{array}{c}\begin{array}{c}\text { Standardized } \\
\text { Coefficient }\end{array} \\
\text { Beta }\end{array}$} & \multirow{2}{*}{$R$ squared } \\
\hline & & & & B & $\begin{array}{l}\text { Standard } \\
\text { Template }\end{array}$ & & \\
\hline \multirow{4}{*}{ 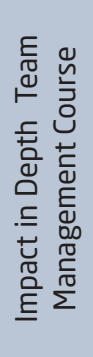 } & \multirow{2}{*}{ 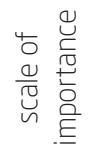 } & \multirow{2}{*}{1} & Constant & 2,23 & 0,15 & & \\
\hline & & & Factor: Unit of Work & 0,17 & 0,02 & 0,43 & 0,18 \\
\hline & \multirow{2}{*}{ 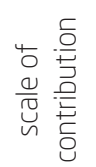 } & \multirow{2}{*}{1} & Constant & 2,02 & 0,16 & & \\
\hline & & & Factor: Unit of Work & 0,19 & 0,02 & 0,43 & 0,19 \\
\hline
\end{tabular}

Source: Elaborated by the author.

\section{(Table 4.2.4)}

SYNTHESIS OF THE EMPIRICAL MODEL - VARIABLE IMPACT CRITERION IN AMPLITUDE ON COMPETENCIES OF THE ATTENDANCE MANAGER AND PREDICTIVE VARIABLE OF LEARNING SUPPORT

\begin{tabular}{|c|c|c|c|c|c|c|c|}
\hline \multirow{2}{*}{ 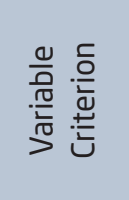 } & & & \multirow{2}{*}{ Model } & \multicolumn{2}{|c|}{$\begin{array}{l}\text { Non-standardized } \\
\text { coefficients }\end{array}$} & \multirow{2}{*}{$\begin{array}{c}\begin{array}{c}\text { Standardized } \\
\text { Coefficient }\end{array} \\
\text { Beta }\end{array}$} & \multirow{2}{*}{$R$ squared } \\
\hline & & & & B & $\begin{array}{l}\text { Standard } \\
\text { Template }\end{array}$ & & \\
\hline \multirow{4}{*}{ 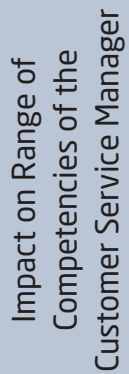 } & \multirow{2}{*}{ 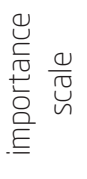 } & \multirow{2}{*}{1} & Constant & 3,11 & 0,08 & & \\
\hline & & & Factor: Unit of Work & 0,07 & 0,01 & 0,36 & 0,13 \\
\hline & \multirow{2}{*}{ 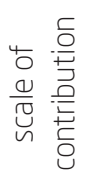 } & \multirow{2}{*}{1} & Constant & 2,26 & 0,10 & & \\
\hline & & & Factor: Unit of Work & 0,15 & 0,01 & 0,53 & 0,28 \\
\hline
\end{tabular}


After the presentation of the empirical results regarding both the evidence of the validity of the questionnaire used and its theoretical dimensions, as well as the statistical regression models, the standard of answers was analyzed among the 291 respondents considering the unit of stocking of the same ones. Basically, ANOVA (analysis of variance) was performed considering as parameter two functions: commissioned function of executive manager and function of manager of the service.

\subsection{ANOVA test results}

In order to analyze the possible influence of contextual factors on the pattern of responses given by the respondents, we chose to perform ANOVA. Firstly, the means of the responses of the training impact items in amplitude were compared between the groups of executive managers and service managers. The total sample contained 30 executive managers and 261 service managers. Although there was a marked difference in the size of the groups, no statistically significant results were observed for the Levene test, which leads to the conclusion that the variances between the groups were homogeneous.

A comparison of means by means of ANOVA showed a non-significant result, $F(1,289)=0.16, p=0.69$, which leads to the conclusion that service managers and executive managers did not differ on the evaluations issued regarding impact in amplitude.

When comparing the two types of function in relation to the assessment of contribution and importance of the strategic management course, it was identified that service managers and executive managers differed in relation to strategic importance assessments $(\mathrm{F}(1,289)=7,12, \mathrm{p}=0.01)$, and for the evaluation of the contribution of the strategic management course, $(\mathrm{F}(1,289)=6.43, \mathrm{p}=0.01)$.

The average number of evaluations of care managers for importance of the strategic management course in the development of their competences was lower $(\mathrm{M}=3.10, \mathrm{SD}=0.67,95 \% \mathrm{CI}[3.02,3.18])$ then $(\mathrm{M}=3.44$, $\mathrm{SD}=0.61$, Bca $95 \% \mathrm{CI}[3.22,3.65])$. The average contribution evaluations of care managers were also lower $(\mathrm{M}=3.02, \mathrm{SD}=0.68,95 \% \mathrm{CI}[2.93,3.10])$ than of the executive managers $(\mathrm{M}=3.35, \mathrm{SD}=0.62,95 \% \mathrm{CI}[3.10,3.56])$.

No significant differences were identified between service managers and executive managers regarding the evaluation of contribution and importance of the Team Management course. This result signals homogeneity in perceptions. The next section presents the discussion of the empirical findings reported here. 


\section{DISCUSSION}

The psychometric indicators obtained in the measures currently discussed were satisfactory and resemble the original measures (Coelho Junior, 2004; Pilati \& Abbad, 2005). The data support evidence of internal validity in the measures used.

The empirical models obtained in this research are in agreement with the scientific literature on TD\&E in demonstrating the importance of psychosocial support to learning in predicting the impact of training at work (Alfandi, 2016; Galanou, \& Priporas, 2009). The variables of training impact, both in terms of amplitude, depth and competences presented acceptable results since the factors unit of work and immediate manager of the predictive variable of learning support demonstrated that it has a strong influence on the training results in the environment job. This is evidenced by the result of the unit work factor $(\beta=0.41)$ and the immediate management factor $(\beta=0.17)$ in the amplitude impact; in $\beta=0.36$ in the immediate management factor of the impact in depth of the scale of importance and in $\beta=0.39$ in the factor of the immediate manager and $\beta=0.18$ of the factor lacking support of the scale of contribution of the course of strategic management. In the course of team management, we can see similar results, with $\beta=0.43$ in the unit of work factor of the importance scale and the same unit work factor with $\beta=0.43$ in the contribution scale. The variable criterion of the impact of training in amplitude on competences was measured as the manager of service, where the result of $\beta=0.36$ was in the unit of work factor of importance scale and of $\beta=0.53$ in the scale of contribution.

In fact, the work environment, represented here by the unit of a work factor, is extremely important to the impact of training actions, and must already be considered in the evaluation of learning needs (Yotamo, 2014). Galanou and Priporas (2009) also identified that training contributed to increased productivity and that the satisfaction level of the team was increased by the training evaluated by the authors. The impact of training on the job generates, in fact, effective contributions to the acquisition and mastery of professional skills of managers (D’Netto, Bakas, \& Bordia, 2008).

Distance training is capable of impacting performance (Vargas, 2003). According to Joia and Costa (2007), it is important to note that there is no single model or formula to guarantee the success of corporate distance training programs. Each company and each training program is unique, with 
specific characteristics that must be observed, so that it is possible to adopt the correct strategies and achieve the desired goals.

Learning support is indispensable in this context since individuals can be the agents that provide or receive the support of colleagues and managers. The meeting with Coelho Junior and Borges-Andrade (2011) identified that support for learning predicts the impact, and this is capable of influencing the development of professional skills.

According to Abbad and Borges-Andrade (2014), Balarin et al. (2014), and Coelho Junior et al. (2005), the support for learning provided in the workplace usually refers to the opportunities for exposing ideas from each server; the time destined for the search of new ways of carrying out the work; the autonomy to argue about leadership demands; error tolerance when trying to apply new knowledge and skills; encouraging the search for new learning; and the availability of material, human, financial and/or informational resources sufficient for the application of new knowledge and skills. The reasons for this lack of support need to be understood qualitatively within this entity.

D’Netto, Bakas, and Bordia (2008) also found predictive relationships between line manager support and the opportunity to effectively use management development actions. The support of the high management level appeared as a strong predictor of the link with the strategy, the latter being the best variable predicting the effectiveness of management development.

None of the personal and professional variables contributed significantly to the empirical models. This result is curious, but it is in line with Abbad and Carvalho (2006) and Yotamo (2014), who also did not identify effects of variables of this nature (gender, age group, educational level, and public prediction of impact.

In summary, the results suggest the need to invest heavily in management actions to provide support for learning, since this support is capable of predicting the impact and influencing the domain of professional skills. By perceiving the organizational environment as sports, workers will be able to apply, in their routines, the skills acquired in a training situation.

\section{FINAL CONSIDERATIONS}

The contributions and limitations of the research are presented, as well as a research agenda for continuity of studies on the impact of training in the 
work environment, since the expectation of finding in the managers' greater control of competences caused by the impact of the training in the work was validated, according to results and discussion presented.

It is salutary to consider the selected public, who at first has decisionmaking power in the organization, not depending on the environment rule to apply the knowledge received in training. However, the statistical regressions, performed and limited in the self-assessment of the research participants, support the need for workplace support to the executive manager and service manager of this autarchy to apply such knowledge.

The present research also allowed the expansion and diversification of samples in the investigations of training impact in the organizations, thus contributing to increase the generalization of the national research results of TD \& E, as recommended by Coelho Junior and Abbad (2010).

Another no less important contribution is the scope of the research carried out, involving a target audience distributed in all Brazilian states both in capitals and in countryside cities. With this unprecedented event, expectations have arisen, and new needs for training actions have arisen in the autarchy, which is in progress.

The verification of the effectiveness of management training in the light of the competences required from managers of this autarchy, as a general objective of this research, was reached in the specific audience of service manager, since it was possible to perform all the factorial analyzes and planned regressions in the sample of this type of manager.

A limitation identified but not impeding its validity and utility, since the elaboration of the research project, was the question of the research being only self-evaluating, disregarding the hetero evaluations, preventing comparisons regarding the effectiveness of the training and the convergence of the answers obtained.

The time interval for the completion of the evaluated training and the accomplishment of this research was also dispersed, averaging ten months, being the ideal to carry out an in-depth impact research before carrying out the specific course, to gauge expectations, another adjacent after the course finished, and another one after six months; thus having an effective evaluation of the impact of training in the work environment. Thus the research would have had a longitudinal rather a transverse cut.

According to the results presented and discussed, the following research agenda is proposed for future studies:

- Evaluate the use of more than one research instrument, in addition to the electronic questionnaire. A mixed research approach could be 
adopted, avoiding the quantitative approach in these cases with restricted public and decision-making power in organizations.

- Perform segmented searches, when there are complex questionnaires with more than one hundred items, where the participant would respond in blocks. Such a division would require a comparative pilot test to gauge the degree of the response rate of the completed and segmented questionnaire, thus deciding on the best return model.

- Continue to apply the instruments built and validated in this study in new organizations, courses, and methodologies, in face-to-face and distance training, using different criteria variables, to confirm their reliability and replication.

\section{A TRÍPLICE ALIANÇA EM AUTOAVALIAÇÃO DE TREINAMENTOS GERENCIAIS}

\section{RESUMO}

Objetivo: A tríplice aliança na autoavaliação de treinamentos gerenciais teve como objetivo geral verificar a influência do suporte à aprendizagem e dos treinamentos gerenciais ofertados a gestores de uma entidade pública federal brasileira sobre a expressão de competências requeridas para o desempenho de suas funções.

Originalidade/relevância: Para o alcance deste objetivo, foi elaborado o modelo teórico hipotetizado de pesquisa tendo como variáveis critérios de impacto de treinamento no trabalho, medido tanto em profundidade quanto em amplitude, mensurado sobre qual foi a importância e contribuição de dois cursos avaliados para a aquisição e expressão das competências laborais gerenciais.

Principais aspectos metodológicos: Quanto à metodologia, foram investigados dois cursos ofertados na modalidade à distância, nesta entidade, que tratavam sobre gestão estratégica e de equipes. A coleta de dados foi realizada à distância. A amostra final $(\mathrm{N}=291)$ era predominantemente masculina, entre 31 a 50 anos e com ensino superior completo.

Síntese dos principais resultados: Os resultados sinalizaram evidências de validade e de construto para as medidas utilizadas, bem como apontaram que suporte à aprendizagem foi importante preditora nos modelos 
empíricos finais. Tendo constante investimento em ações de melhoria do suporte à aprendizagem no ambiente organizacional, tais gestores podem aplicar em suas rotinas as competências adquiridas em situação de treinamento, de uma forma mais perene, impactante e alinhada com os objetivos estratégicos da entidade.

\section{PALAVRAS-CHAVE}

Impacto do treinamento no trabalho. Suporte à aprendizagem. Competências organizacionais. Resultados de treinamento. Gestão de pessoas.

\section{DEFERENCES}

Abbad, G. (1999). Um modelo integrado de avaliação do impacto do treinamento no trabalho - IMPACT (Doctoral dissertation). Universidade de Brasília, Brasília, DF, Brazil.

Abbad, G. S. (2014). Necessidades e impactos de treinamento e programas educacionais no trabalho e nas organizações (Pedido de renovação de bolsa de produtividade $\mathrm{CNPq}$ ). Universidade de Brasília, Brasília, DF, Brazil.

Abbad, G. S. (2007). Educação à distância: O estado da arte e o futuro necessário. Revista do Serviço Público, 58(3), 100-110.

Abbad, G. S., \& Borges-Andrade, J. E. (2014). Aprendizagem humana em organizações e trabalho. In J. C. Zanelli, J. E. Borges-Andrade, \& A. V. B. Bastos (Orgs.), Psicologia, Organizações e Trabalho no Brasil (pp. 244-284). Porto Alegre, RS: Artmed.

Abbad, G. S., \& Carvalho, R. S. (2006). Avaliação de treinamento a distância: reação, suporte, transferências e impactos no trabalho. Revista de Administração Contemporânea, 10(1), 95-116. doi:10.1590/S1415-6555200 6000100006

Abbad, G. S., Sallorenzo, L. H., Coelho Junior, F. A., Zerbini, T., Vasconcelos, L., \& Todeschini, K. (2012). Suporte à transferência de treinamento e suporte à aprendizagem. In G. Abbad, L. Mourão, P. P. M. Meneses, T. Zerbini, J. E. Borges-Andrade, \& R. Vilas-Boas (Orgs.), Medidas de avaliação em treinamento, desenvolvimento e educação (pp. 244-263). Porto Alegre, RS: Artmed. 
Aguinis, H, \& Kraiger, K. (2009). Benefits of training and development for individuals and teams, organizations, and society. Annual Review of Psychology, 60, 451-474.

Alfandi, A. M. (2016). Training impact on the performance of employees "A case of jordanian travel and tourism institutions". International Business Management, 10(4), 377-384.

Balarin, C. S., Zerbini, T., Martins, L. B. (2014). A relação entre suporte à aprendizagem e impacto de treinamento no trabalho. Revista Eletrônica de Administração, 20(2). doi:10.1590/1413-2311017201341925

Bloom, B. S., Hastings, T., \& Madaus, G. (1983). Manual de avaliação formativa e somativa do aprendizado escolar. São Paulo, SP: Pioneira.

Borges-Andrade, J. E. (1982). Avaliação somativa de sistemas instrucionais: Integração de três propostas. Tecnologia Educacional, 11 (46), 29-39.

Borges-Andrade, J. E. (2006). Avaliação integrada e somativa em TD\&E. In J. E., Borges-Andrade, G., Abbad, L., Mourão (Orgs.), Treinamento, desenvolvimento e educação em organizações e trabalho: Fundamentos para a gestão de pessoas (pp. 343-358). Porto Alegre, RS: Artmed.

Boyatzis, R. E. (1982). The competent management: A model for effective performance. New York, NY: John Wiley.

Brandão, H. P., Borges-Andrade, J. E., Freitas, I. A., \& Vieira, F. T. (2010). Desenvolvimento e estrutura interna de uma escala de competências gerenciais. Psicologia: Teoria e Pesquisa, 26(1), 171-182.

Brandão, H. P., Borges-Andrade, J. E., \& Guimarães, T. A. (2012). Desempenho organizacional e suas relações com competências gerenciais, suporte organizacional e treinamento. Revista de Administração, 47(4), 523-539.

Campos, E. B. D. (2015). Competências empreendedoras: Uma avaliação no contexto de empresas juniores brasileiras (Doctoral dissertation). Universidade de Brasília, Brasília, Brazil.

Carbone, P. P. (2009). Gestão por competências e gestão do conhecimento (3rd ed.). Rio de Janeiro, RJ: Editora FGV.

Churchill Junior, G. A. (1999). Marketing research: Methodological foundations (7th ed.). Fort Worth: The Dryden Press.

Coelho Junior, F. A. (2004). Avaliação de treinamento a distância: Suporte à aprendizagem e impacto do treinamento no trabalho (Master's thesis). Universidade de Brasília, Brasília, Brazil.

Coelho Junior, F. A., \& Abbad, G. (2010). Construção e validação de uma escala de avaliação de impacto em profundidade de um treinamento a distância em uma organização do setor bancário brasileiro. Revista Eletrônica de Administração, 16(1), 91-119. 
Coelho Junior, F. A., \& Borges-Andrade, J. E. (2011). Efeitos de variáveis individuais e contextuais sobre desempenho individual no trabalho. Estudos de Psicologia, 16(2), 111-120.

Coelho Junior, F. A., Abbad, G., \& Todeschini, K. C. (2005). Construção de validação de uma escala de suporte à aprendizagem no trabalho em uma instituição bancária brasileira. Revista Psicologia Organizações e Trabalho rPOT, 5(2), 167-196.

Creswell, J. W. (2010). Projeto de pesquisa: Métodos qualitativo, quantitativo e misto (3rd ed.). Porto Alegre, RS: Artmed.

Denhardt, R. B. (2012). Teorias da administração pública. São Paulo, SP: Cengage Learning.

D’Netto, B., Bakas, F., Bordia, P. (2008). Predictors of management development effectiveness: an Australian perspective. International Journal of Training and Development, 12(1), 2-23.

Elnaga, A., \& Imran, A. (2013). The effect of training on employee performance. European Journal of Business and Management, 5(4), 137-147.

Freitas, H., Oliveira, M., Saccol, A. Z., \& Moscarola, J. (2000). O método de pesquisa survey. Revista de Administração, 35(3), 105-112.

Galanou, E., \& Priporas, C. V. (2009). A model for evaluating the effectiveness of middle managers' training courses: Evidence from a major banking organization in Greece. International Journal of Training and Development, 13(4), 221-246. doi:10.1111/j.1468-2419.2009.00329.x

Hair Junior, J. F., Black, W. C., Babin, B. J., Anderson, R. E., \& Tatham, R. L. (2006). Multivariate Data Analysis (6th ed.). Upper Saddle River, NJ: Pearson Prentice Hall.

Hamblin, A. C. (1978). Avaliação e controle do treinamento. São Paulo, SP: McGraw-Hill do Brasil.

Kirkpatrick, D. L. (1976). Evaluation of training. In R. L. Craig, \& L. R. Bittel (Eds.), Training and development handbook (pp. 87-112). New York, NY: McGraw Hill.

Kraiger, K.; Cavanagh, T. M. (2015). Training and personal development. In K., Kraiger, J., Passmoore, N. R., Santos, \& S., Malvezzi (Eds.), The Wiley Blackwell handbook of the psychology of training, development, and performance improvement (pp. 227-246). West Sussex: John Wiley \& Sons.

Kimura, H. (2015). Editorial. RAC - Revista de Administração Contemporânea, 19(3), 1-5. 
Malvezzi, S. (2015). The history of training. In K., Kraiger, J., Passmore, N. R., Santos, \& S., Malvezzi (Eds.), The Wiley Blacwell handbook of the psychology of training, development, and performance improvement (pp. 13-31). West Sussex: John Wiley \& Sons.

Mcclelland, D. C. (1973). Testing for competencies rather than for intelligence. American Psychologist, 28(1), 1-14. doi:10.1037/h0034092

Meneses, P. P. M., Coelho Junior, F. A., Ferreira, R. R., Paschoal, T., Silva Filho, A. I. (2014). A produção científica brasileira sobre a gestão de recursos humanos entre 2001 e 2010. Revista de Administração Mackenzie, 15(4), 110-134. doi:10.1590/1678-69712014/administracao.v15n4p110-134

Noe, R. A., Clarke, A. D. M., \& Klein, H. J. (2014). Learning in the twentyfirst century workplace. Annual Review of Organizational Psychology and Organizational Behavior, 1, 245-275. doi:10.1146/annurev-orgpsych-031 413-091321

Pereira, L. M. R., Loiola, E., \& Gondim, S. M. G. (2016). Aprendizagem de competências, suporte à transferência de aprendizagem e desempenho docente: Evidências de validação de escala e teste de relações. Organizações E Sociedade, 23(78), 438-459.

Pilati, R., \& Abbad, G. (2005). Análise fatorial confirmatória da escala de impacto do treinamento no trabalho. Psicologia: Teoria e Pesquisa, 21 (1), 43-51.

Salas, E., Tannenbaum, S. I., Kraiger, K. Smith-Jentsch, K. A. (2012). The science of training and development in organizations: What matters in practice. Sage Journals, 13, 74-101. doi:10.1177/1529100612436661

Sandberg, J. (1996). Human competence at work. Göteborg: BAS.

Tabachnick, B. G. \& Fidell, L. S. (2007). Using Multivariate Statistics (5 th ed.). Boston, MA: Allyn and Bacon.

Warr, P. B., Bird, M. W., \& Rackham, N. (1970). Evaluating of management training. Londres, UK: Gower Press.

Yotamo, C. J. (2014). Avaliação de impacto de treinamento no desempenho de servidores públicos de Sofala em Moçambique (Master's thesis). Universidade de Brasília, Brasília, DF, Brazil. 


\section{(APPEndiX)}

(Appendix 1)

\section{PARTIAL FACTORIAL LOADS OF SUPPORT BLOCKS FOR TRAINING LEARNING AND IMPACT}

\section{(Table 1)}

PARTIAL FACTORIAL LOADS OF THE LEARNING SUPPORT BLOCK

\begin{tabular}{|c|c|c|c|c|}
\hline \multirow{2}{*}{ Learning Support Item } & \multicolumn{4}{|c|}{ Factor* } \\
\hline & 1 & 2 & 3 & 4 \\
\hline There is opportunity to display ideas for each server & 0,68 & & & \\
\hline $\begin{array}{l}\text { It assumes with me the risks of trying new ways of doing } \\
\text { the work }\end{array}$ & & 0,81 & & \\
\hline $\begin{array}{l}\text { Ignores the changes that I propose based on what I learned } \\
\text { in training }\end{array}$ & & & & 0,44 \\
\hline
\end{tabular}

It gives me the freedom to decide on how to perform my tasks

Note: Remark 1: * Factor = 1 - Work Unit, 2 - Immediate Manager, 3 - Work Team, 4 - Inadequate Support. Remark 2: Extraction method: Main component analysis.

Source: Elaborated by the author.

\section{(Table 2)}

PARTIAL FACTORIAL LOADS OF THE AMPLITUDE TRAINING BLOCK UNIFORMS SOLUTION

\begin{tabular}{lc}
\hline \multicolumn{1}{c}{ Item } & $\begin{array}{c}\text { Factor } \\
1 \text { - Impact }\end{array}$ \\
\hline When I apply what I have learned in training, I carry out my work more safely & 0,83 \\
\hline I remember well the contents taught in the training & 0,77 \\
\hline
\end{tabular}

Note. Remark 1: Extraction method: Main component analysis.

Source: Elaborated by the author. 


\section{(Table 3)}

PARTIAL LOADS OF THE IMPACT BLOCK SOLUTION IN DEPTH STRATEGIC MANAGEMENT COURSE

\begin{tabular}{lcc}
\hline \multicolumn{1}{c}{ Strategic Management Course Item } & $\begin{array}{c}\text { Importance } \\
\text { Scale Factor }\end{array}$ & $\begin{array}{c}\text { Contribution } \\
\text { Scale Factor }\end{array}$ \\
\hline Enable the application of strategic objectives in my unit of work & 0,90 & 0,91 \\
\hline Promotes strategic management practices in my unit of work & 0,87 & 0,85 \\
\hline
\end{tabular}

Note. Remark 1: Extraction method: Main component analysis.

Source: Elaborated by the author.

\section{(Table 4)}

PARTIAL LOADS OF THE IMPACT BLOCK SOLUTION IN DEPTH TEAM MANAGEMENT COURSE

\begin{tabular}{lcc}
\hline \multicolumn{1}{c}{ Team Management Course Item } & $\begin{array}{c}\text { Importance } \\
\text { Scale Factor }\end{array}$ & $\begin{array}{c}\text { Contribution } \\
\text { Scale Factor }\end{array}$ \\
\hline I discuss actions mobilizing performance with the work team & 0,89 & 0,89 \\
\hline $\begin{array}{l}\text { I stimulate in the work environment the formation of new } \\
\text { leadership }\end{array}$ & 0,82 & 0,90 \\
\hline
\end{tabular}

Note. Remark 1: Extraction method: Main component analysis.

Source: Elaborated by the author.

\section{(Table 5)}

PARTIAL LOADINGS OF AMPLITUDE TRAINING IMPACT BLOCK UNIFORMS SOLUTION ON SERVICE MANAGER SKILLS SCALES IMPORTANCE AND CONTRIBUTION

\begin{tabular}{lcc}
\hline \multicolumn{1}{c}{ Competency Item for the Service Manager } & $\begin{array}{c}\text { Importance } \\
\text { Scale Factor }\end{array}$ & $\begin{array}{c}\text { Contribution } \\
\text { Scale Factor }\end{array}$ \\
\hline Get productivity at work & 0,55 & 0,40 \\
\hline Find quality in decisions & 0,51 & 0,54 \\
\hline Promote the personal and professional development of the team & 0,54 & 0,46 \\
\hline
\end{tabular}

Note. Remark 1: Extraction method: Main component analysis. 


\section{() Arrtoen Wort}

Leovanir D. D. Richter, Mestre em Administração, Faculdade de Economia, Administração e Contabilidade (FACE), Universidade de Brasília (UnB), ORCID:0000-0003-1165-2971.

Leovanir D. D. Richter is now at Ministério da Transparência e Controladoria Geral da União (CGU) as an Analist from the Executive Secretary.

Correspondence concerning this article should be addressed to Leovanir D. D. Richter, Quadra Interna QI 09, Conjunto R, Casa 15, Guará, Brasília, DF, Brazil, CEP 71020-188.

E-mail: leovanir@yahoo.com.br

\section{EDITORIAL BOARD}

Editor-in-chief

Silvio Popadiuk

Associated Editor

Silvia M. R. Domenico

Technical Support

Vitória B. S. Silva

\section{EDITORIAL PRODUCTION}

Publishing Coordination

Irina Migliari

Language Editor

Daniel Leão

Editorial Trainee

Layout Designer

Maria Luiza Vanz

Emap

Copyeditor

Irina Migliari
Graphic Designer

Libro 